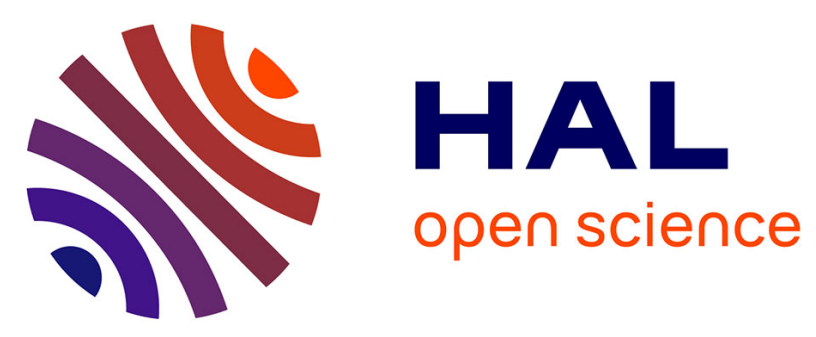

\title{
Cholesterol and Sitosterol, Two Members of the Steroid Family That Differ in Structure by a Single Ethyl Group Yet Maintain the Right Balance between Plant and Animal Kingdoms \\ Jean-Louis Kraus
}

\section{To cite this version:}

Jean-Louis Kraus. Cholesterol and Sitosterol, Two Members of the Steroid Family That Differ in Structure by a Single Ethyl Group Yet Maintain the Right Balance between Plant and Animal Kingdoms. Bioorganicheskaya Khimiya / Russian Journal of Bioorganic Chemistry, 2020, 46 (5), pp.869-872. 10.1134/s106816202005012x . hal-03141442

HAL Id: hal-03141442

https://hal-amu.archives-ouvertes.fr/hal-03141442

Submitted on 15 Feb 2021

HAL is a multi-disciplinary open access archive for the deposit and dissemination of scientific research documents, whether they are published or not. The documents may come from teaching and research institutions in France or abroad, or from public or private research centers.
L'archive ouverte pluridisciplinaire HAL, est destinée au dépôt et à la diffusion de documents scientifiques de niveau recherche, publiés ou non, émanant des établissements d'enseignement et de recherche français ou étrangers, des laboratoires publics ou privés. 


\title{
New manuscript revised version
}

\section{Title}

Cholesterol and Sitosterol, two members of the steroid family which structures differ by a single ethyl group, but which maintain the right balance between plant and animal kingdoms.

\section{Author adress}

\author{
Jean-louis Kraus \\ Professor Aix Marseille University \\ Institut de Biologie du Développement de Marseille (IBDM), \\ UMR-7288 CNRS-Aix Marseille University \\ Campus de Luminy, Case 907 \\ 13288 Marseille Cedex \\ France \\ Email : jean-louis.kraus@univ-amu.fr \\ Tel : (33) 0413942425
}

\begin{abstract}
Cholesterol and Sitosterol are two members of the steroid family, which molecular structures differ only by the presence of an ethyl substituent at the position 24 of the steroid skeleton. Cholesterol is mainly synthesized in large quantities in the liver of animals and only in small quantities by plants. In contrast Sitosterol is only synthesized by plants. This tiny difference of an ethyl group between the two steroids structures have induced profound effects on the climatic changes during evolution, but plant sterols still have important effects on cholesterol metabolism on humans.
\end{abstract}

\section{Key words}

Steroids, cholesterol, sitosterol, plants, animals, metabolism 


\section{Introduction}

Liver is an organ only found in vertebrates, which has a significant capacity to regenerate. Remember the myth of Prometheus, bound to a mountain in the Caucasus, where an eagle ate a piece of his liver every day, only to have it grow back to be eaten the next day. Liver has many important metabolic functions, mainly it converts diet nutrients into substances easily metabolized. Among these substances Cholesterol, produced and cleared by the liver, is essential. Since plants don't have liver, a large majority of people, believe that plants do not synthesized cholesterol and consequently a plant-based diet ensures to be cholesterol free.

This belief is due to several reasons. Generally, plants contain only small quantities of cholesterol, and analytical methods for cholesterol detection in plants are not as developed as they are for mammals. Moreover very often legalities of food labelling, allow small quantities of cholesterol in foods which are still called "zero cholesterol " [1,2]. Sitosterol, which differs from cholesterol (scheme 1 ), by an ethyl susbtituent at position 24 , is the most common, but depending on the species, plants also contain amounts of free or esterified cholesterol [3]. In plants, cholesterol is a major sterol mainly found on the surfaces of leaves, and localized in membranes. Nevertheless, it should be underlined that cholesterol averages are around $50 \mathrm{mg} / \mathrm{kg}$ in plants and around $5 \mathrm{~g} / \mathrm{kg}$ in animals. Besides the little contents of cholesterol, the most common sterol components of plants membranes are sitosterol ( $\beta$ form), and stigmasterol. The differences in cholesterol levels between plants and animals and the presence of specific sterols in plants not found in humans, have opened up number of questions:

-Why does the parent precursor epoxysqualene (scheme 1) gives birth to lanosterol and cycloartenol, each other giving rise respectively to cholesterol in larger quantities in animals and sitosterol and stigmasterol in larger quantities in plants?

-Do plant sterols affect cholesterol levels in humans

-Do animals metabolize plant steroids by the same mechanism with which they metabolize cholesterol?

-Why, if some animals need an external supply of cholesterol, they eat preferentially another animal and not plants? 
Finally, those issues lead to raise a basic question directly linked to the darwinian evolutionist theory: "Why plant don't have a liver?"

\section{Discussion}

\section{1 -Plants and animals, steroids biosynthesis}

Answering the above questions requests to take into account other matters. Since plants unlike animals, cannot move; they must protect themselves from cold and heat. In this feature, Sitosterol allows plants to have a better adaptation to large temperature variations. In contrast, nature has endowed animals with a liver, a specific organ dedicated to cholesterol production. Since animals move, first they can exploit other sources of cholesterol in eating other animal species, and second they can adapt themselves to different climatic conditions in finding a shelter to protect themselves from heat and cold.

\section{Scheme 1}

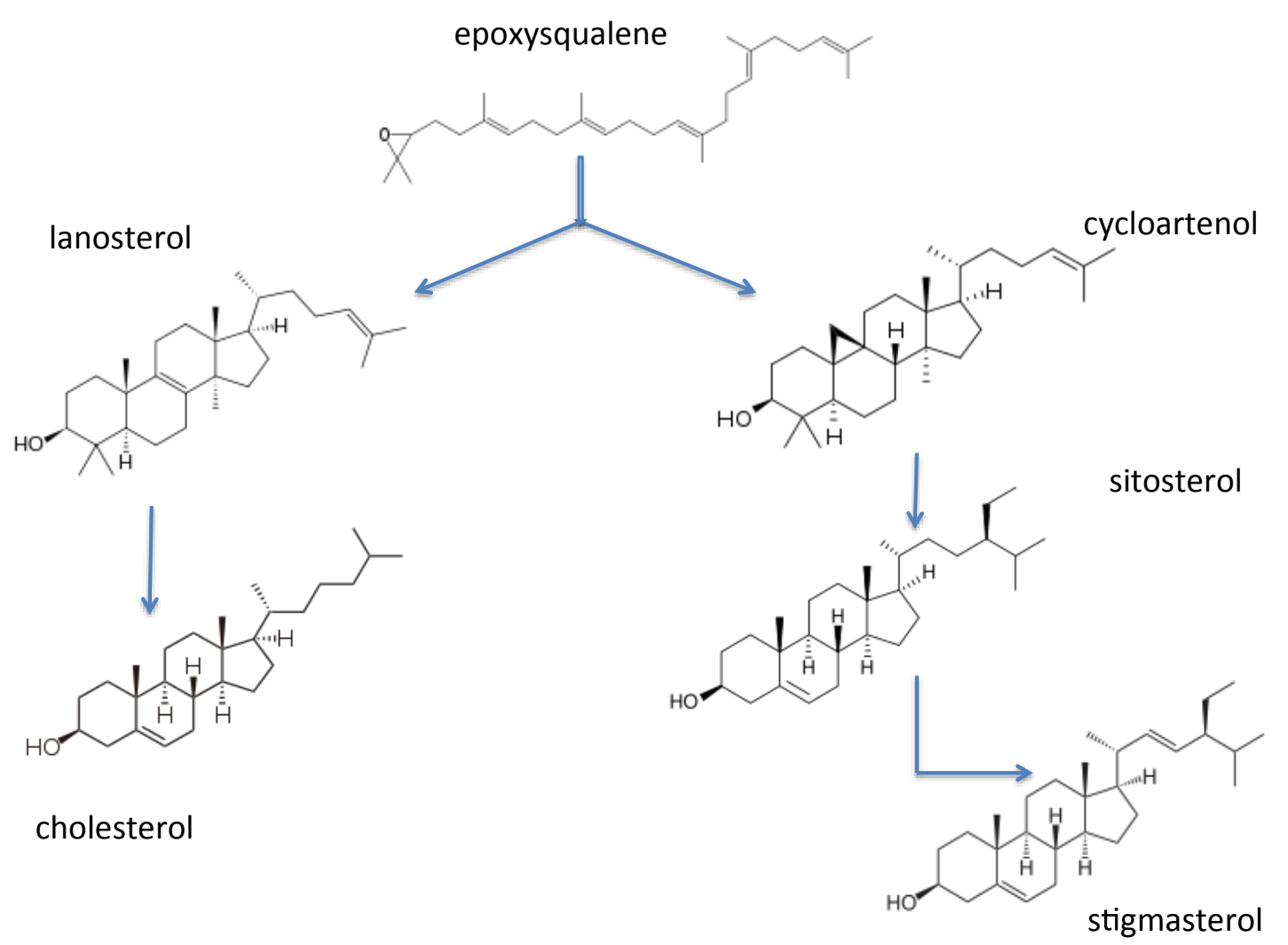

As shown on Scheme 1, both animals and plants steroids derived from the same precursor epoxysqualene, which gives rise respectively to lanosterol and cycloartenol. Lanosterol is the 
precursor of cholesterol, while cycloartenol is the precursor of silosterol and stigmosterol. Lanosterol pathway leading to cholesterol is more developed in animal kingdom. In contrast cycloartenol pathway leading to sitosterol and stigmasterol is specific to plant kingdom, both sterols cannot be metabolized by animals. It can be concluded that in contrast to cholesterol, precursor of sexual steroids hormones in mammals (estrogens and androgens), sitosterol cannot be converted in animal sexual hormones [4]. Taking into account these observations, it is tempting to conclude that nature has allowed plants to remain motionless, by endowing them with a system of sterol production, available directly from soil nutriments, and not metabolized by animals.

The above considerations suggest that a profound coupling between nutrition and reproduction exists. This coupling is after all logical, since in the course of evolution, only those who have been well fed, have been able to successfully launch into reproduction, which is a very expensive activity in energy. This coupling nutrition /reproduction implies that hormones constantly ensure a coordination between the physiological state and the entry into phase of reproduction.

\section{2-What are the effects of plant steroids on cholesterol levels in humans?}

Some uncomplete answers to the question, "what are the effects of plant sterols on cholesterol levels on humans" have been brought by Garett [5], but the question still remains hot. Levels of cholesterol in western diet are still major sources of conflict among dietetic specialists. It is likely that some therapists recommend medicinal plants for lowering cholesterol and glucose levels [6] and in the same time, controversies agitate the world of medicine between pro and anti-statins for the treatment against high levels of blood cholesterol [7]. The paradox is that when rice is cultivated in the presence of yeast species such as monacus purpureus, it produced compounds like lovastatin or compactin, which are statin drugs, which inhibit cholesterol synthesis by blocking action of the enzyme HMG-CoA reductase [8]. That being said, cholesterol remains an appealing molecule which best illustrates the relationships that have been developed during evolution between animal and plant kingdoms. For animals, that need a lot of energy to get around, nature has provided them with a liver that allows them to synthesize significant amounts of cholesterol for the biosynthesis of hormones necessary for their reproduction. In contrast plants that are motionless, synthesize their own specific sterols (sitosterol and stigmasterol) and only low 
amounts of cholesterol. Mother nature has made that less than $5 \%$ of plant sitosterol are absorbed by the intestine of the animals. This was possible since nature has allowed plants to lower cholesterol levels in animal, simply in organizing a competition between plants sterols and cholesterol for packaging into mixed micelles that are taken up by polytopic transmembrane protein called Niemann-Pick C1-Like 1 (NPC1L1) [9] which is highly expressed in human liver.

\section{3-Steroids and determinism.}

In the light of what has been said above, it is interesting to reassess the key role of both steroids, Cholesterol and Sitosterol, in the life evolution process on earth.

Those two legitimate signaling molecules, have helped and continue to maintain the right balance between the two kingdoms : plants and animals. Upsetting this balance, would have had profound effect on life earth, mainly in weathering changes due to the content of $\mathrm{CO}_{2}$. The story is quite simple: Herbivores evolve to eat plants, the plants evolve ways of eluding the herbivores, and the herbivores evolve again. As each side gets the upper hand, it changes the weathering rate, which in turn steers the planet between balmy and cold climates.

Plants have been land-colonizers for around roughly 700 million years. Vertebrates first came on land about 360 million years ago, almost without exception they were carnivore. Humans have been only around for the last 200,000 years or so. During the paleozoic era, plants did well, because nothing was around yet to eat them. $\mathrm{CO}_{2}$ level in the air was low. To handle terrestrial plants, animal evolved with a digestive system completed with grinding teeth, symbiotic gut bacteria, and powerful gastrointestinal tract; at the same time as plants struggled under attacks from herbivores, earth basked in a heat wave for the next 200 million years due to an increase of $\mathrm{CO}_{2}$ level in air. Could someone seeing cows grazing placidly in a lush grass meadow, imagine that life on earth has been possible because nature has provided animals not only a liver, but also a digestive system that allowed them to handle plants? This system works through the molecular language based on two steroids molecules: Cholesterol provided by the liver of the animals, and sitosterol synthesized by plants.

Conclusion. What can we have learned from this steroid story? Confirmation that a communication exists between animals and plants. It is well known that plants can release 
coercive chemicals to pollinators or attractants to species that eat their pests, eventually they can exudate substances from their roots, but cherry on the cake, plants can synthesize secret hypoglycemic statins that have the property of inhibiting cholesterol animal production [10]. Unfortunately nobody knows to what end or whether this is truly intentional. Nevertheless, if the deterministic theory is true, all the events that occur, were necessitated by a past situation. Therefore weathering or climates changes which occur millions year ago, for which to-day humans are still responsible, are associated at least in part, to the communication that exist between plants and animals, through a simple fundamental molecular steroid language based on two molecules cholesterol and sitosterol .

\section{Acknowledgments.}

Institut de Biologie du Développement de Marseille (IBDM), Aix-Marseille-University and CNRS-UMR 7288 from France are acknowledged for financial support. A. Le Bivic and L. Kodjabachian, IBDM-CNRS Marseille directors, are greatly acknowledged for facilities offered.

\section{References .}

1-Gyling, H. and Simonen, P. Phytosterols, phytostanols and lipoprotein Metabolism . Nutrients, 2015, Vol 7 (9), pp.7965-7977; doi: 10.3390/nu7095374 PMCID: PMC4586569 PMID: 26393644

2-Valitova, J.N, Sulkarnayeva, A.G, and Minibayeva F.V. Plant sterols: diversity, biosynthesis and Physiological functions. Biochemistry (Mosc) , 2016, Vol : 81(8) pp.819-834 doi: 10.1134/S0006297916080046.

3-Behrman, E.J. Venkat Gopalan. Cholesterol and plants. J. Chem. Educ., 2005, 82, 17911793.DOI :10.1021/ed082p 1791.

4- Raquel, D. Integrative Medicine. Elsevier Editions Inc, Book 4th edition. 2018. ISBN 978-0323-35868-2 
5- Garrett, R.H. Grisham, C.M. Biochemistry BookS-Cole. Belmont C.A. 2005 ; p 263. https://trove.nla.gov.au/version /46533475

6-Tappia, P.S.; Xu Y-J.,Dhalla, N.S. Reduction of cholesterol and other cardiovascular disease risk factors by alternative therapies. Clin. Lipidology, 2013, 8(3), 345-359.

https://doi.org/10.2217

7- Even, P. La vérité sur le cholestérol. Cherche-Midi Editions. 2013. ISBN 274913014X, 9782749130149 .

8- Edwards, J.E. Moore, R.A. Statins in hypercholesterolaemia: A dose-specific meta-analysis of lipid changes in randomised, double blind trials". BMC Family Practice. 2003, 4 :18 doi:10.1186/1471-2296-4-18. PMC 317299. PMID 14969594.

9- Betters, J.L; YU, L. NPC1L1 and cholesterol transport. FEBS Lett., 2010, 584 (13) $2740-$ 2747.DOI: 10.1016/j.febslet.2010.03.030

10 - Khanimov, I., Segal, G., Wainstein, J. Boaz, M., Shimono, M., Leibovitz, E. High-intensity statins are associated with increased incidence of hypoglycemia during hospitalization of individuals not critically III. Am. J. Med, 2019, Jun22. Pii: S0002-9343 (19) 30451-6 . doi: 10.1016/ j. amjmed. 2019.04050. 